BEFORE / NOW

Vol. 1 No. 1

Lime industry; the building industry; Cartels; Limeburners Point; Melbourne. (c) The Author(s) [2019].

Published by the Collaborative Research Centre in Australian History, Federation University Australia. All rights reserved.

\section{The Port Phillip Lime Economy}

\section{Peter Taylor}

\begin{abstract}
Lime is an essential component of the building industry for it is used to make mortar and to make plaster. Without lime, building construction in Melbourne would have been severely curtailed. Yet, this is an industry rarely written about. Using newspapers as a key source, this article discusses the development of the lime industry from the time of first settlement in the Port Phillip district to the rise of Marvellous Melbourne in the 1880s, key figures in the industry, and their predilection to form cartels.
\end{abstract}

\section{Introduction}

The aim of this paper is to present a linear overview of the development and decline of the local Port Phillip lime industry, from its inception until the land-boom of the 1880s and subsequent collapse in the 1890s, and to view this concurrently with the growth of Melbourne. The consumption of lime is examined to see whom, or what industries were using the product with estimations, and costings of that being used. As Harrington stated: 'It is probably no exaggeration to state that lime made an important contribution to the physical development of Victoria. [And the colony] was literally built on lime..."

The lime industry cannot be examined properly without a look into the activities of the once mighty individuals and companies that dominated the trade during the nineteenth-century. This paper looks at those relationships and seeks to explain the lengths organisations would pursue to maintain market dominance.

As with other types of economies, the Port Phillip lime economy operated on supply and demand. Lime was desperately needed during the nineteenth-century to help with the physical construction of Melbourne. This demand created a market for locally produced lime that was eagerly sought by builders and later gas companies. The lime economy also created a need for local craft to transport the material across the waters of Port Phillip and employed 25 craft in $1849 .{ }^{2}$ The flow-on effect was to create employment within and outside the immediate limeburning and quarrying industry, and with lime-capital distributed amongst quarry workers, limeburners, labourers, blacksmiths, captains and crew, boatbuilders, cartage contractors, clerks, victuallers, builders and gas companies.

To manufacture lime required a source of calcium carbonate; that compound could have come in the form of seashells or limestone. The source product was burnt in a lime kiln where the carbon dioxide was driven off and the raw material calcined. The lime produced was known by a variety of names including roche, rock or quick lime; it was all the same. It was, in some instances, soaked in water to stablise this highly volatile product for transportation over water, and to prevent the possibility of a fire. This was known as slaked or slack lime. It could be applied to walls and ceilings as a hard-white plaster or mixed with sharp sand to become mortar.

Limeburning commenced at Sullivan Bay (Sorrento) in 1803-1804, when an unsuccessful attempt was made by the NSW government to set up a southern colony in the district 
of Port Phillip. The local limestone was burnt and used to construct chimneys for the inhabitants. ${ }^{3}$ It was many years after the abandonment of the Sullivan Bay settlement that limeburning recommenced. In the mid-1830s the new and expanding settlement of Melbourne created a demand for one of the most basic building materials: lime. A second major source of limestone was discovered at Limeburners Point, Geelong in the 1830s, with limeburning being undertaken by the late 1830s. ${ }^{4}$

\section{The rise and decline of Marvellous Melbourne through the lens of the lime economy}

So farewell Melbourne the Marvellous, city of towering warehouses, Parliament Houses

- the new one as yet unfinished-law courts, free libraries, a colonial post-office, a monumental town-hall, colleges, institutes, cathedrals, churches and chapels innumerable, stately Government offices, multitudinous drinking bars - of which the sprightly barmaids are threatened with extinction under clauses of Mr. Berry's new Licensing Bill. Farewell Melbourne, city of handsome, elegant, and well-patronised theatres. ${ }^{5}$

Sala's observations of Melbourne, the Paris of the south, ${ }^{6}$ lauded the remarkable development of the city. The small settlement founded on the banks of the Yarra River in 1835 was completely transformed by the gold rushes of the 1850s and the subsequent capital brought to the town: 'it [gold] quickened the normal beat of the Port Phillip pulse to a fever point; crowded Hobson's Bay with ships [1], and started, not only a new era for the city, but a new outlook...'

Importation of lime to Melbourne began as early as 1836 when the 217-ton brig Stirlingshire was chartered by the government of New South Wales to bring convicts, troops, and officials, to the recently established settlement in the Port Phillip District. ${ }^{9}$ The cargo included building materials and 1.4 tons of lime.10 Other cargoes followed. On March 24 1837, the 127-ton government schooner Isabella departed Sydney for Port Phillip and carried government personnel, building materials and 640 kilograms of lime for cottage of the new administrator for the Port Phillip District, William Lonsdale." There followed a steady stream of imports from other British colonies. In 1838, a total of 23 tons of lime valued at $£ 142.60$ arrived.12 Importation increased to 58.8 tons for the year of 1839.13 The increased amounts of imported lime helped to reactivate the Port Phillip lime trade, for lime was being sold for approximately 1.80 shillings per 32 kilograms (one bushel).

As well as such imports, a local industry was emerging. In early December 1837, limeburning at Port Phillip began when convicts were assigned to collect seashells for the production of lime and, within a year, they were further tasked with calcining the seashells for local building works. Shells were also dredged from Hobsons Bay and the Yarra River, by small sailing craft of three to tens tons with any quantity available from suppliers..$^{14}$ By February 1839, limeburning in Melbourne, by private industry, was considered a nuisance occupation with residents complaining of the suffocating smoke produced by limeburners. ${ }^{15}$

Initially, the Port Phillip economy was based in the pastoral industry, settlers importing 15,035 sheep from Launceston between October 1835 and October 1836. ${ }^{16}$ There was yet to be an established manufacturing or industrial base, which were still some years into the future. Yet, this was also a period of a mini-land boom where the prices of blocks of land near the customs reserve in Melbourne soared within a short amount of time; with two blocks of land rising from a purchase price of $£ 23$ to $£ 1,224$ by late February 1839.17 
BEFORE I NOW

Vol. 1 No. 1

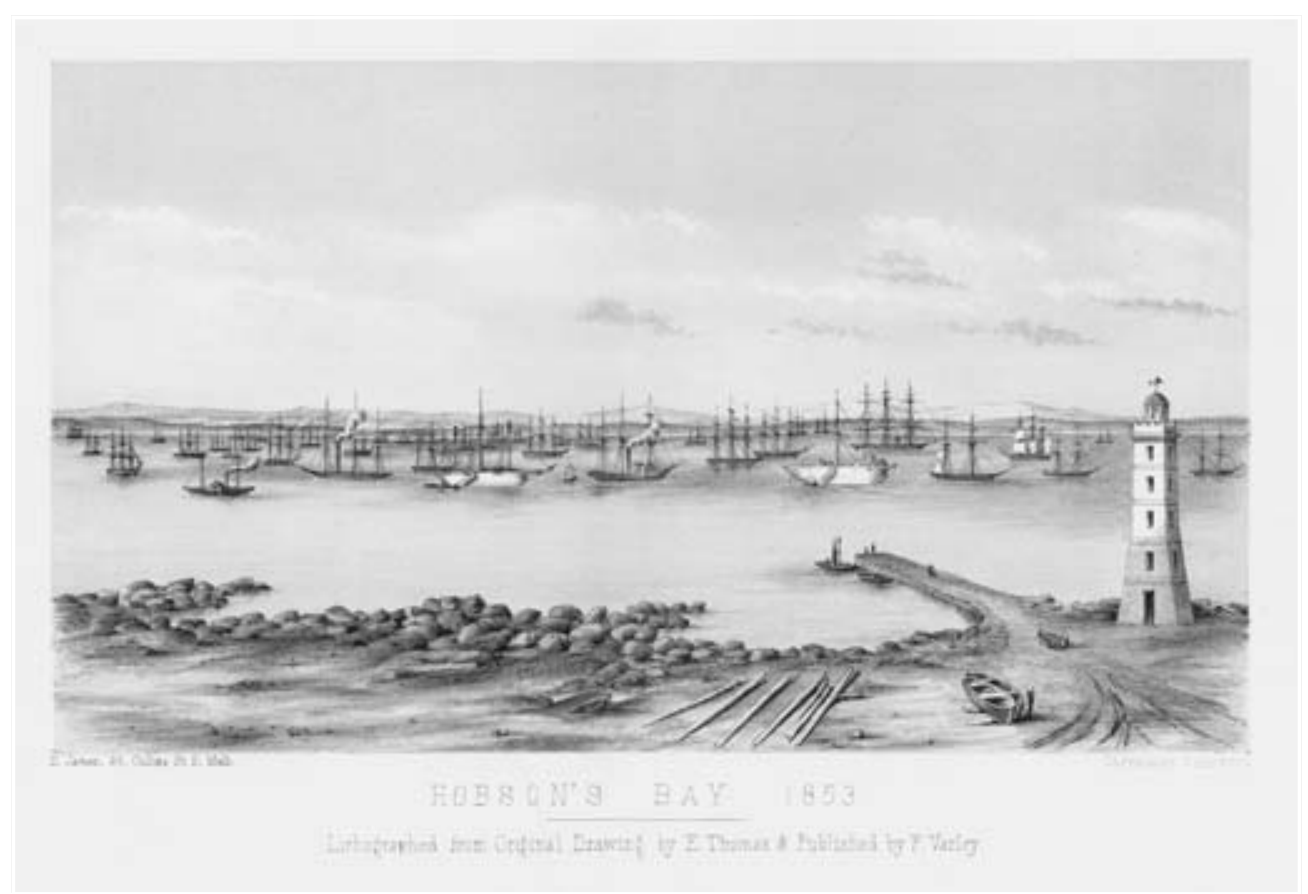

FIG 1 / Ships at Anchor Hobsons Bay. D. James and Edmund Thomas. HOBSON'S BAY 1853 [picture] / D., 1853. State Library Victoria (SLV) Picture Collection, H90.91/600.

Such an expenditure of capital in the local economy stimulated the need for building construction, and bricks were in short supply. To help meet this demand they were shipped in from other Australian colonies, making some importers prosperous as supply was unable to meet demand..$^{18}$ Melbourne pioneer John Pascoe Fawkner, for example, used his vessel Enterprise to ship in bricks from Launceston in April 1836.19 Others, sensing an opportunity, utilised craft as small as the 10-ton sloop Childe Harold, which in March 1837 brought over bricks and other construction materials from Launceston. ${ }^{20}$

The demand for bricks grew and, in October 1838, 90,000 were sold for $£ 1.50$ per thousand ${ }^{21}$ requiring an estimated 19 tons of lime to be laid at a ratio of one part lime to three parts sand. ${ }^{22}$ This lime then had to be sourced from either local or intercolonial markets. The freshness of lime was important, which may have favoured local lime. Again, Fawkner showed his business acumen shipping limestone and lime from Point Nepean to Melbourne in the Enterprise. ${ }^{23}$

Melbourne was expanding at a steady pace and by June 1837 there were 250 people and 36 buildings. Two years later, June 1839, there were 560 buildings. ${ }^{24}$ The structures had a combined estimated value of $£ 169,542 .{ }^{25}$ The settlement continued to grow with both permanent structures and residents. By October 1840, the population increased to 5,538 , and an accompanying 932 buildings. ${ }^{26}$

The economy of Port Phillip was slowly growing as pre-gold rushes import and export figures demonstrate. There were regular deficits each year from 1838; however, by 1843 there was a surplus of $£ 95,000$ over imports. ${ }^{27}$ By 1852 gold exports from Victoria were booming with an estimated 1,974,975 ounces which had a value of $£ 8,110,703$, being shipped to the United Kingdom. In contrast the value of imports equated to $£ 4,069,742$, leaving a healthy balance of payments of over $£ 5,000,000 .{ }^{28}$

The gold rushes brought thousands of immigrants into Victoria, with approximately 192,000 arriving between 1852 and 1853, inclusive. ${ }^{29}$ The population boom created opportunities for accomplished building artisans including: stonemasons, carpenters and 
bricklayers, whereby their skills commanded high wages. With the frontier nature of the gold rushes and the nouveau riche gold miners, Melbourne was becoming an eyesore with boiling down works, mud holes and stranded steamers on the banks of its once beautiful river. ${ }^{30}$

From the 1850s, the town and its civicminded citizens were clearly attempting to turn Melbourne into a sophisticated southern capital. Part of the beautification included an art gallery at Melbourne's Mechanics' Institute that displayed a collection of over 400 paintings as well as ceramic models, many the products of colonial artists. A new town hall was almost finished

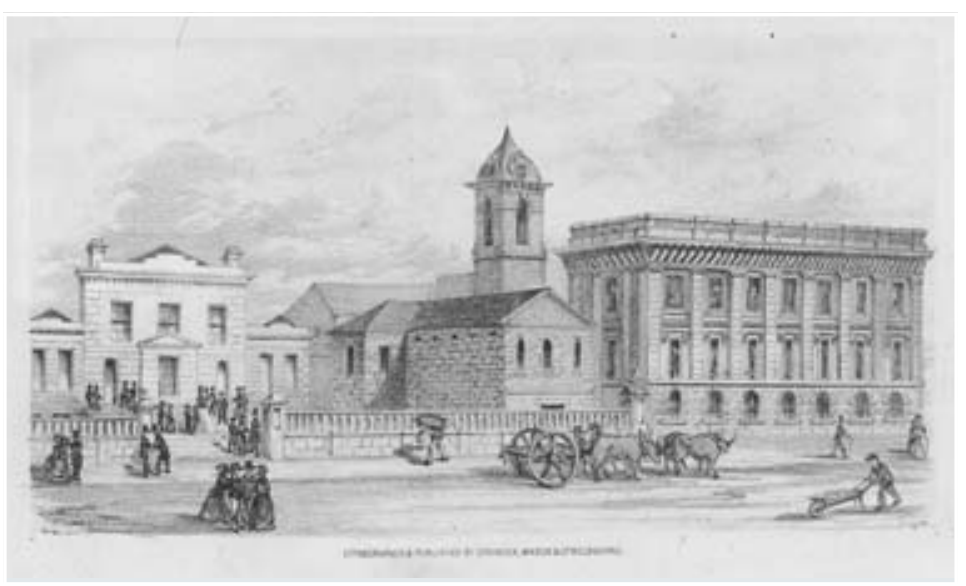

FIG 2 / Police station and Town Hall, 1853.

Stringer, Mason \& Co. Engravers. TOWNHALL \& POLICE COURT [picture] / Stringer, Mason \& Co., 1853.

SLV Picture Collection, $\mathrm{H} 4226$. [2], featuring a statue of Queen Victoria.

Stone buildings were being erected throughout the city, with the Post Office being expanded to encompass 1000 post boxes for 'merchants and residents', and prime city land selling for ' $E 150$ per foot'. ${ }^{31}$ With the building work being undertaken and the employment of numerous mortar-trade artisans, the demand for lime followed a parallel course of growth.

Although gold production was creating remarkable export figures there were still periods of depression within Victoria as the markets were flooded with imports and too few consumers to take up the excess. ${ }^{32}$ As supply exceeded demand, prices were forced down with merchandise lying unclaimed on wharves. ${ }^{33}$ The lethargic state of the economy was followed by a depression in $1854 .{ }^{34}$ Causes were attributed to a number of factors including the reduced output of gold from 14,866,799 ounces in 1852 to a yield of $8,770,796$ ounces in 1854 . As a result of the weak economy, wages were reduced-decreasing the incomes and the purchasing power of the consumer. Victoria's economic problems were further exacerbated by too much money invested in land ('without cultivating, or developing it' [for commercial purposes]), excessive government debt and too many imports including basics such as wheat for bread making. ${ }^{35}$ This depression had a flow-on effect in the building industry with contractors taking on work at less than the cost of materials. ${ }^{36}$ Wages for stonemasons and bricklayers ebbed and flowed during the mid-1850s when daily rates for stonemasons peaked at 30 shillings, in $1853 .{ }^{37}$ By 1857 this had been reduced to 16 shillings, with up to 600 stonemasons being unemployed. ${ }^{38}$

In the early 1860s a number of brick companies modernised production methods with the importation of brick making machines that were able to produce up to 25,000 bricks per day. ${ }^{39}$ By late 1864. Melbourne brick works were manufacturing up to $1,000,000$ bricks per week. ${ }^{40}$ At the time, the building trade was brisk as stonemasons, bricklayers and plasterers were employed erecting a number of multi-storey buildings of brick, stone and render; consuming hundreds of tons of lime. It was not just in the central city that buildings were being erected at a frenetic pace, but also in the surrounding suburbs of Carlton and North Melbourne where the number of dwellings were increasing too. A great many hastily erected buildings of early periods were being replaced with those of a more elaborate style as Melbourne and its investors found the funds for the new works. ${ }^{41}$ There were, in 1864, 1,750 artisans who made use of lime in the building trade, with 900 masons, 350 bricklayers and 500 plasterers. ${ }^{42}$ 
BEFORE / NOW

Vol. 1 No. 1
Lime was also used in the production of gas from coal for it took one bushel of lime to purify 10,000 cubic feet of gas, or 32 kilograms of lime to purify 280 cubic metres of gas. ${ }^{43}$ As Melbourne grew, from the mid-1850s, gas street lighting and gas cooking became a possibility for those in the surrounding suburbs of Melbourne. The Melbourne Gas Company commenced supplying gas to Melbourne in 1856 and quickly became a successful business. Between 1856 and the end of 1859, 4,461,857 cubic metres of gas was produced, requiring an estimated 510 tons of lime.

Production of gas at the Melbourne Gas Company had commenced in 1856 and the business quickly became successful. During the 1860s, production greatly increased during the 1860s with a total of 26,751,864 cubic metres of gas produced between 1860 and 1869 inclusive. $^{44}$ Half yearly reports from mid-1867 and early 1868 show the Melbourne Gas Company purchased an estimated (by cubic metres of gas produced) 467 tons at a cost of $£ 636.10$, paying 1.15 shillings per 32 kilograms. ${ }^{45}$ As the gas market proved to be so successful other companies inaugurated operations such as the Williamstown Gas Company which commenced production in 1866. ${ }^{46}$ Previous to this the Collingwood Gas Company began to 'supply of gas in May 1861'. ${ }^{47}$ This company also consumed many tons of lime, with $£ 477.80$ being expended on lime during 1869.48 Five years later, in the second half of 1874, an estimated 2,352,000 cubic metres of gas was produced in the first twelve months. ${ }^{49}$ The figures for the consumption of lime by the gas companies confirm the importance of the supply of this vital product. Hundreds of tons were required each year to help to maintain the development of these important utilities, and to help drive the modernisation of Melbourne. The consumption of lime by the gas companies alone, without taking into account the consumption by the building trade, would have kept many in the lime business busy, as well as the flow-on effect to supporting industries.

\section{The corporatisation of the lime economy 1852-1875}

The gold rushes and accompanying building boom heralded a paradigm shift for the lime trade from an artisan industry to one with a corporate identity. Big players, including Charles Campbell, William Lang, James Mixner, Henry Dyer and William Blair, moved in on the lucrative trade. These hard-nosed businessmen were driven by profit and expected efficiencies of scale and their names were synonymous with the industry for many years throughout the latter half of the nineteenth-century. Cartels formed and fought to maintain their dominance of Victoria's lucrative lime business during the nineteenth-century, and parallels can be seen in today's business atmosphere where certain companies or corporations, in their quest for excessive profits, apply whatever means, available, to take control markets.

William Blair, Charles Campbell and James Mixner were successful Melbourne businessmen with interests in lime kilns, sailing craft, and retail outlets for local lime, imported cement and building materials. In the mid-1860s, they formed the most powerful lime-cartel of the time and had a number of confrontations with a group of Melbourne builders who sought an equal footing. The last two of interest to the understanding of the cartels, are William Lang and Henry Dyer, who were also successful lime and cement retailers while also investors in lime kilns, quarries and sailing craft.

Campbell and Blair ran a hegemonic system at Limeburners Point. The limestone was of such quality that serious discussions were held by Geelong businessmen to develop 'Limeburners Point marble' on a commercial level..$^{50}$ It was a freshwater limestone of far better quality than the stone found on the western Mornington Peninsula between Rye and Point Nepean, which was dune limestone [3], having a white earthy appearance..$^{51}$ 
The lime produced on the Mornington Peninsula was considered suitable mainly for plastering. ${ }^{52}$ The superior characteristics, and strength, of Limeburners Point lime made it suitable for 'concrete foundations or building purposes... 53 As such, Limeburners Point lime was used extensively throughout Melbourne for construction, both as plaster and mortar, and was required for most government contracts. ${ }^{54}$ This very valuable resource was a guaranteed and continuous means of generating revenue to whoever could control it.

First registered in early September 1865, ${ }^{55}$

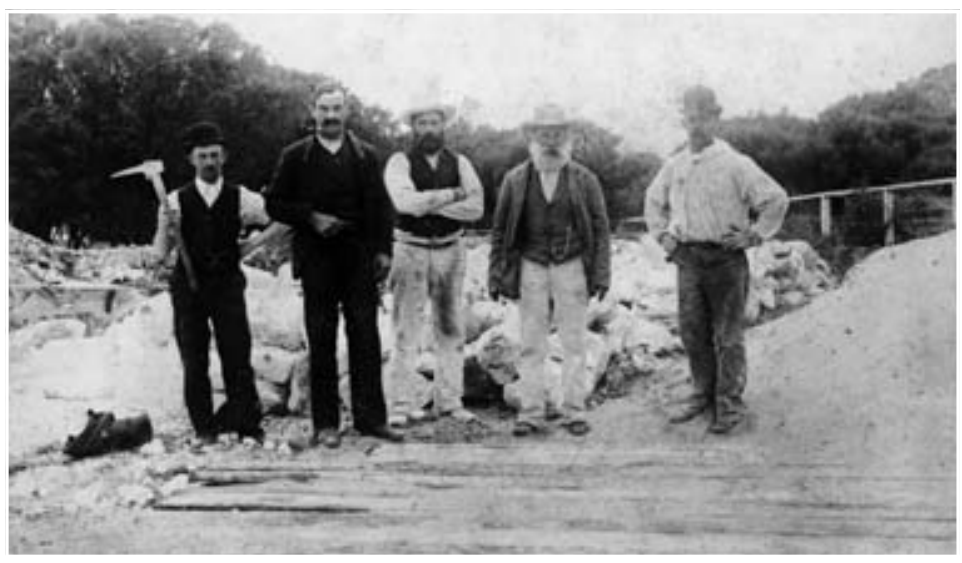

FIG 3 / Limestone Workers.

Nepean Historical Society Picture Collection, VNEP P1234. the Victoria Lime and Cement Company (VLCC) is important to understanding the corporatisation process of the lime trade. The company appears to have filled the void left when Henry Dyer sold his lime and cement business, in January $1865 .^{56}$ The original VLCC partnership consisted of William Blair, George Cakebread and Henry Hall, with the partnership being dissolved in $1872 .{ }^{57}$

By 1874 new partners bought into the VLCC and consisted of: William Blair (598 shares), Charles Campbell (145 shares) and James Mixner (145 shares). This select group formed a partnership in the Limeburners Company that controlled a number of kilns at Limeburners Point. Where the Victoria Lime and Cement Company started, and where the Limeburners Company ended is opaque. It appears that the main purpose of operating two separate companies was to exclude competition from others at Limeburners Point, for the Limeburners Company quarried and burnt the lime, whilst the Victoria Lime and Cement Company sold the product. The size of the business at Limeburners Point cannot be underestimated as it produced two-thirds of the building lime used within Victoria. ${ }^{58}$ The continuous output helped to drive the lime economy, keeping up to five vessels in fulltime employment..$^{59}$

During 1865, the rumblings of discontented builders, including the prominent Melbourne builder David Mitchell, surfaced. Mitchell was a prominent Melbourne builder who had emigrated from Scotland in 1857 where he was trained as a stonemason. A very successful businessman, he was the main contractor for the Melbourne exhibition building, as well as a number of churches and other imposing structures. ${ }^{60}$ Builders talked of forming a company to handle their own lime in order to avoid dealing with VLCC. ${ }^{61}$ The early 1870s saw the long simmering dispute erupt, with warring camps composed of builders, who required the product, and suppliers who sought to keep a close rein on supply.

A key factor for the establishment of a new alliance of builders to control the supply of lime was their exasperation at the lime cartels constantly overcharging for underweight bags of lime. Their talk and hubris did not go unnoticed by the lime merchants. Methods of intimidation were surreptitiously applied to individual builders who were threatened that if they did proceed they might 'regret' that decision. The progress of change was slow and it was not until October 1874 that the Melbourne Builders' Lime and Cement Company (MBLCC) formally elected directors and issued shares. ${ }^{62}$ To further stamp its authority and independence, the MBLCC sought to charter its own vessel. ${ }^{63}$ The long thought out move was an instant success for, within 
BEFORE I NOW

Vol. 1 No. 1

a few months of commencing operations, the company became so profitable that it could return $£ 1$, for each share taken out. ${ }^{64}$ This action would no doubt have been considered a frontal assault on Campbell's and Blair's interests in the Limeburners Company for it was their company that supplied the MBLCC with lime from their Limeburners Point kilns.

The builders eventually achieved some success with autonomy and reducing the power of the once mighty cartel. ${ }^{65}$ Yet the VLCC continued to use aggressive business techniques. In January 1875, the government advertised for tenders to operate two sites at Limeburners Point. The builders soon found themselves out manoeuvered when Campbell and Blair out-bid them, offering $£ 1,500$ per site, when the expectation was in the region of $£ 500 .{ }^{66}$ The builders cried foul, but it appears that the government could not refuse such a lucrative offer.

Yet, the industry was not restricted to sourcing lime from Limeburners Point for it was also found at Limeburners Creek, eight kilometres to the northwest of Limeburners Point, on the opposite shores of Corio Bay, a supply first discovered in $1838 .{ }^{67}$ The area was called Duck Ponds. The eponymous lime had similar characteristics to that at Limeburners Point and, when tested under the direction of the Minister for public works, was found to exceed the strength and adhesive properties of Limeburners Point lime. ${ }^{68}$ Melbourne builders were aware of this and acquired as much Duck Ponds lime as they could from limeburners Robert Walker, who managed MBLCC's lime kiln, and John Spalding who ran his own kiln. ${ }^{69}$

Trade in lime at Duck Ponds was strong. With access to the nearby railway line, restrictions that faced a sail powered vessel that relied on fair winds to move the product to market in Melbourne were eliminated. In October 1874, 442 tons of lime was sent from Duck Ponds railway station to Melbourne, by rail. ${ }^{70}$ The MBLCC sought to have their lime recognised as suitable for government contracts as VLCC held a monopoly of Limeburners Point lime. As a tactical manoeuver to try and break this monopoly, and to challenge the dominance of Limeburners Point lime, they were willing to take a reduction of six pence per bag. ${ }^{71}$

Even though the MBLCC established some degree of power, with the operations at Duck Ponds, swindling by the Geelong suppliers did not stop, as can be seen by an audit of the lime cargo of the MBLCC's vessel Result. Builders were still required to purchase lime from the cartel for certain building contracts. When independent auditors examined and weighed a random sample of twenty bags taken from the builders' vessel Result, the short weight of the bags was immediately apparent, amounting to an under-supply of 40 percent. ${ }^{72}$ Tensions between the two groups continued and soon the MBLCC were again in dispute with VLCC as they sought to fulfil bi-monthly orders that consisted of 45.6 tons per order. In what may have been an act of retaliation, VLCC claimed that they could not supply the builders for they consistently sold out the product. ${ }^{73}$

\section{Boom and Bust}

After Melbourne's building booms of the 1850s and 1860s, another followed during the 1880s. Old structures were again demolished and replaced with substantial new edifices. Money appeared to be no object. Charles James' new six-storey office block in Collins Street west, almost opposite Market Street was to cost $£ 24,000$, with its ornate red marble staircase calculated to be an extra $£ 2,400$, and an elevator costing substantially more. ${ }^{74}$ James was to crash severely during the 1890 s depression losing his 
entire fortune, built up through his speculative ventures in land deals. ${ }^{75} \mathrm{~A}$ confident Melbourne appeared to be fully in the grip of a building frenzy, with buildings being erected all over the city, expanding on the elegance of the great southern metropolis. ${ }^{76}$ Such was the demand for building materials that in 1888 40,000 bricks were required for a proposed railway station at Albert Park; no tenders were submitted. ${ }^{77}$

Hoffman bricks [4], based in Brunswick, further increased the efficiency of its plant in the early 1880s insomuch as it was able to produce $40,000,000$ bricks per annum, with deliveries being made by a special branch line off the main Brunswick rail line. ${ }^{78}$ Hoffman Patent Brick and Tile Company operated on a 4.9 hectare site at Albert Street Brunswick, commencing in 1870. The company was noted for its huge 'Hoffman kilns' that allowed for a more efficient method of manufacturing bricks, by continually loading bricks. ${ }^{79}$ In order for these bricks to be laid with lime mortar at a ratio of 1:3 would have required, an estimated, 8,398 tons of roche lime. This figure, for lime, does not include that required for the millions of bricks produced by other brick manufacturers, or the lime required for plastering, laying stone or gas production. The delivery of lime from the Mornington Peninsula and Limeburners Point to Melbourne, to meet this need, would have required hundreds of trips for the fleet of lime-craft [5].

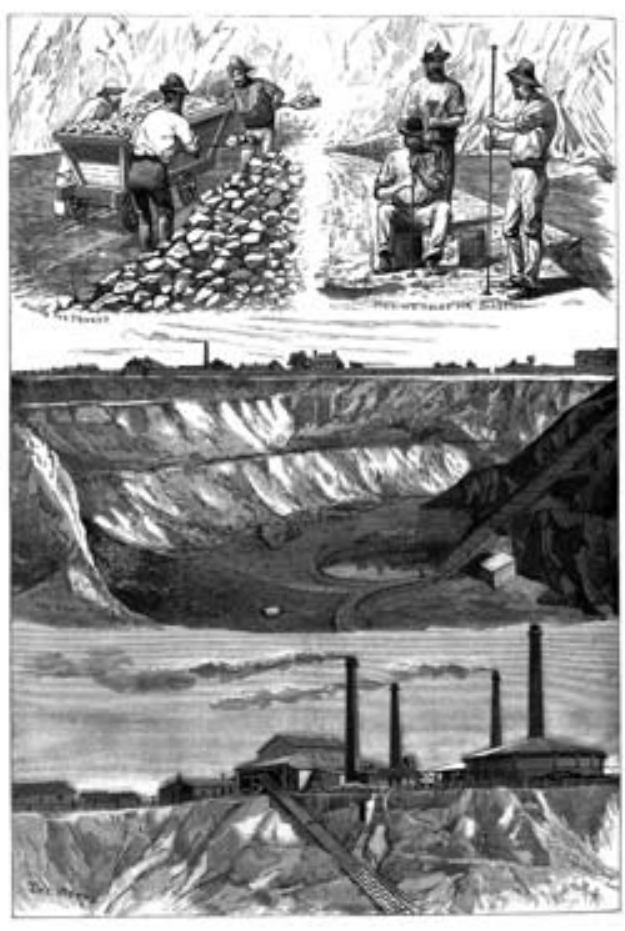

FIG 4 / Hoffman brickworks 1881. Julian Rossi Ashton. Victorian Industries [picture]: The Hoffman Brick Company's Works, Brunswick, 1881.

SLV Picture Collection, A/S19/11/81/372.

The balance of trade figures, however, demonstrated that the boom times of Marvellous Melbourne were built on shaky ground. The import / export data for the years of 1884 to 1889 clearly illustrate a growing disparity. Trade was in deficit for each year, commencing at $£ 3,151,368$ in 1884 and increasing to $£ 12,006,866$ by 1889 , a total of $£ 42,175,511$ over six years. ${ }^{80}$

Signs of a crisis began as early as 1889 when the overheated silver and land markets crashed, with a flow on effect with the mining industry. ${ }^{81}$ This did not prevent the construction of a new stock exchange building in Queen Street, with ornately carved stone columns from the Bendigo district. ${ }^{82}$ By the early 1890 s, the boom years were showing signs of a weakening economy with merchants carrying excess stock and the building trade slowing down. ${ }^{83}$ Dubious financial practices were allowed to continue as building societies lent money to speculators who attempted outbid other speculators in great land grabs, without any apparent repercussions or methods of control. ${ }^{84}$ While the finger could be pointed towards such narrow causations fields, the problem of stagnation did in fact extend beyond the shores of Australia. The 1890s depression was not just a localised event but a world-wide phenomenon, as the UK, Europe and North America were facing a similar bleak outlook. A significant catalyst for the difficulties facing the global economy was the gold standard on which the financial system of trade operated. The lack of newly mined gold entering reserves to balance world trade contributed to the under-valuing of commodities, and therefore affected the income streams of countries, world-wide..$^{85}$

The effect of the depression on the local Port Phillip lime-craft would have caused concern to those directly involved and also those indirectly involved, such as ship owners, and ships' captains and crew. The vessels may have shifted to other trades such as lightering, ballasting, general cargo work or laid up at anchor, until the work 
BEFORE I NOW

Vol. 1 No. 1 came in again. The building trades were affected too, with an estimated 3,000 being without work, and a further 2,000, outside the trades being unemployed, in $1892 .{ }^{86}$ This too would have decreased the demand for lime and employment opportunities for associated occupations, leading to financial distress, a byproduct of unemployment.

\section{Conclusion}

The lime industry was an important contributor to the development of Melbourne. At its peak in the 1880s, the flow-on effect it created by keeping lime-capital within the colony effectively employed, directly and by association, thousands of people. The 1890s depression was not the end of Melbourne or the lime trade, but a realignment of the previous power structures. It can also be seen, that Australia was not isolated from the world economy and that problems with the global economic system could affect local industry and employment.

The period between settlement and the depression was dynamic as the lime trade moved from a mostly imported product to one that was locally manufactured; firstly through collecting and dredging seashells, and secondly to the development of extensive infrastructure surrounding the quarrying and calcining of limestone. Although ruthless, the lime cartels were important as they moved the somewhat artisan pre1850s limeburning operations to a more efficient model. However, by doing so they maneuvered VLCC into a position where it owned the quarries, kilns, sailing craft and retailing operations, therefore creating a monopoly that effectively stymied competition, for many years. They were to later find the tables turned when discoveries of high quality limestone were made around Lilydale and Bacchus Marsh and these new sources brought serious competition into the market.

The only survivor of the early lime industry, and of interest to this paper, was the Cave Hill operations at Lilydale, a company which only that ceased production in 2015. The limestone quarries and kilns at Duck Ponds, Limeburners Point and the western Mornington Peninsula all eventually closed. The sailing craft disappeared from the

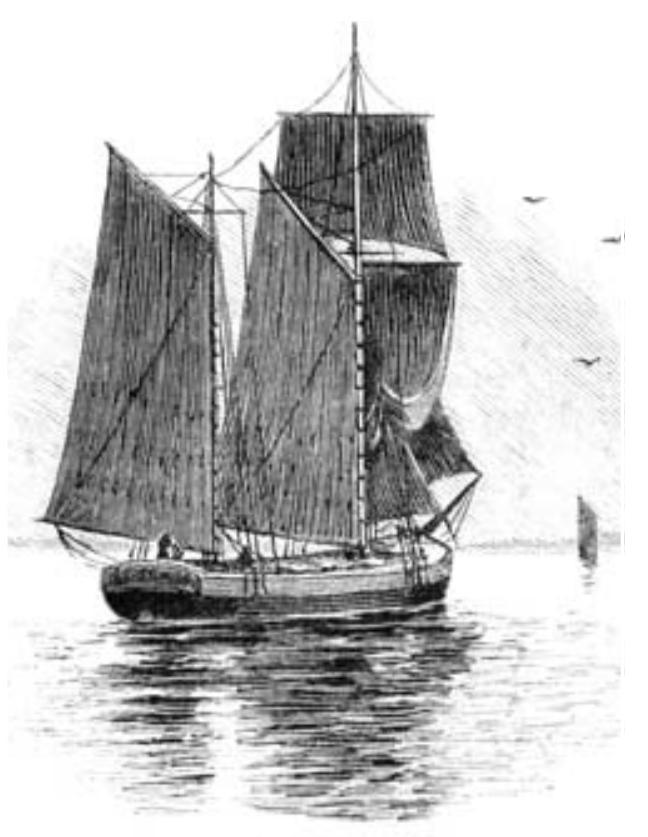

FIG 5 / Lime Craft Port Phillip 1886. LIME CRAFT. [picture], 1886.

SLV Picture Collection, IAN18/12/86/SUPP/16. waters of Port Phillip too. Modern technology had eventually caught up with these antiquated operations. Just as the important figures of the mid-late nineteenth century lime industry faded from memory, so too, knowledge of the lime industry itself has faded, even though without lime the buildings of Marvellous Melbourne would not have risen. These buildings are the physical manifestation of the lime industry, yet the formation and operation of lime cartels can provide lessons for today. Lime should not be forgotten.

\section{Peter Taylor | PhD candidate}

CRCAH, Federation University Australia

Email: petertaylor@students.federation.edu.au

Peter Taylor completed his Master of Arts at Federation University and is commencing doctoral studies. He has an interest in the lime industry that sprang from a ten-year career as a practicing stonemason, and 30 years as a stonemasonry lecturer.

This research is supported by an Australian Government Research Training Program (RTP) Fee-Offset Scholarship through Federation University Australia. 


\section{Notes}

1 Jane Harrington, An Archaeological and Historical Overview of Limeburning in Victoria (Melbourne: Heritage Council, 2000), 1.

2 "Domestic Intelligence: re New Lime Dock," Argus, 16 February, 1849, 4.

3 Charles Hollinshed, Land Lime Leisure: Peninsula History in the Shire of Flinders, (Melbourne: Shire of Flinders, 1982), 30.

4 Rod Elphinstone, Limeburners Point Historic Site [report], (Melbourne: National Trust of Australia [Victoria], 1980), n.p.

5 George Sala, "The Land of the Golden Fleece, IX Melbourne to Adelaide," Argus, 31 August, 1885: 7.

6 "As Others See Us," Herald, 27 December, 1887, 4.

7 Miles Lewis, Melbourne: The City's History and Development (Melbourne: City of Melbourne, 1995); Alexander Sutherland, Victoria and Its Metropolis: Past and Present, Vol. 1, 1888; Andrew Brown-May, Shurlee Swain, The Encyclopedia of Melbourne (Cambridge: Port Melbourne, Vic., Cambridge University Press, 2005; Ian Morrison, Ian Stuart, A New City: Photographs of Melbourne's Land Boom (Carlton: Miegunyah Press, 2003).

8 J.B. Cooper, Victorian Commerce 1834-1934, Melbourne, (Melbourne: Robertson \& Mullins LTD., 1934), 73.

9 "Shipping Intelligence, Departures," Sydney Gazette and New South Wales Advertiser, 27 September, 1836: 2.

10 Pauline Jones, editor, Historical Records of Victoria: Foundation Series: vol. 1: Beginnings of Permanent Government, (Melbourne: Victorian Government Printing Office 1981) 156.

11 "Shipping Intelligence, Departures," Australian, 28 March, 1837, 2., Jones, 1981: 161.

12 Michael Cannon, editor-in-chief, Historical Records of Victoria, vol.4; Communications, Trade and Transport 18361839 (Melbourne: Victorian Government Printer 1985), 245.

13 Cannon 1985, 250.

14 Peter Taylor, The Port Phillip Lime Economy: the Vessels, the Industry and Their Decline, MA Thesis, (Ballarat: Federation University 2017), 28. https://trove.nla.gov.au/version/254134735

15 Port Phillip Patriot and Melbourne Advertiser, 27 February, 1839, 4.

16 Marten Syme, Shipping Arrivals and Departures: Victorian Ports vol.1 1798-1845. Note: author tabulated the number of sheep that arrived at Melbourne using Syme's arrival reports, 1984, 14-19.

17 "Land Mania," Port Phillip Patriot \& Melbourne Advertiser, 27 February, 1839, 4.

18 Cooper 1934, 10.

19 Syme, 1984: 15.

20 Syme 1984, 20.
21 "Domestic Intelligence, Auctions," Port Phillip Gazette, 27 October, 1838: 3.

22 author calculated the ratio of bricks to volume of lime with a 10 millimetre joint between bricks. At an estimate 100 bricks would require a total of approximately 20.8 kilograms of dry mortar mix, http://www.limemortars.co.uk/calculators/mortar, (accessed August 9, 2017). At a ratio of one part lime to three parts sand, this would equate to approximately 20.8 kilograms of lime (lime being lighter in volume as compared to coarse sand). This then provides a divisor of 4.8 that can be used to calculate the kilograms of lime required for a standard brick of $21.5 \times 10.2 \times 6.5$ centimetres. E.g. 100 bricks $\div 4.8=20.8$ kilograms lime, or 45.8 pounds.

23 John Pascoe Fawkner, "Shipping Intelligence, arrival of Enterprise from Point Nepean with lime and stone," Melbourne Advertiser, 1 January, 1838, 4

24 Cooper, 1934, 20.

25 Cooper, 1934, 20.

26 Cooper, 1934, 20.

27 "Our Commercial Department," Age, 17 October, 1854, 4.

28 'Imports and Exports,' Argus, 3 June, 1853, 4.

29 Cooper, 1934, 74.

30 "Houses for Australia, Melbourne and Colonial House Investment Company," The Banner (Melbourne newspaper), 30 December, 1853, 5.

31 "A Few Words for Our Home Readers," The Banner, 23 September, 1853, 7.

32 "Melbourne Markets," Geelong Advertiser, 12 December, 1853, 5.

33 Geoffrey Serle, The Golden Age: A History of the Colony of Victoria 1851-1861 (Melbourne: Melbourne University Press 1977), 121.

34 "Finance and Commerce," Age, 28 November, 1854, 4.

35 "The Causes of Colonial Depression," Age, 9 April, 1855, 5.

36 "Domestic Intelligence, Labour Contracts," Age, 10 January, 1855: 5.

37 "Advertising, Wanted Immediately ... several good stonemasons," Argus, 11 August, 1853, 1.

38 "Employed Masons in Melbourne and Their Doings, To the Editor of the Argus," Argus, 18 September, 1857, 5.

39 "Current Topics, new brick making machine on display at Geelong," Geelong Advertiser, 24 January 1860, 2.

40 "Conditions of Labour, No. XVII.- The Brickmakers," Argus, 29 September, 1864, 6.

41 "Building Operations in Melbourne," Argus, 11 August, 1865, 5.

42 "Co-Operation, To the Editor of the Age, table concerning the number of carpenters, masons, bricklayers and plasterers," Age, 25 May, 1864, 7. 
43 "Experiments With Wood Gas," Leader, 9 November, 1867, 27.

44 "Improvements at The Melbourne Gas Works, table of gas production 1856 to 1867 inclusive," Argus, 23 October, 1868, 6; "The Melbourne Gas Company's New Gasometer, gas production output for 1868, and projected output for 1869," Weekly Times, 9 October, 1869, 11.

45 "The City of Melbourne Gas and Coke Company, report of the shareholders' seventeenth AGM," Age, 23 July, 1867:5; "Financial report inclusive of December 1867," Age, 22 January, 1868, 5.

46 "The Chronicle, Williamstown lit by locally produced coal gas in 1866," Williamstown Chronicle, 7 August, $1875,2$.

47 Ray Proudley, Circle of Influence: a history of the gas industry in Victoria (Melbourne: Hargreen Publishing and the Gas and Fuel Corporation of Victoria, 1987), 49.

48 "Law Report, Collingwood Gas Company v. Mayor of Fitzroy," Argus, 1 April, 1870, 6.

49 "News of the Day, half-yearly general meeting held by the company," Age, 28 January, 1875, 2.

50 "The Geelong Preliminary Marble Company," Geelong Advertiser, 16 December, 1862, 2.

51 Mr. Daintree, "Report on the Geology of the District from Bacchus Marsh to Bass's Point, Pliocene Tertiary Epoch," Age, 26 May, 1863, 7.

52 Weekly Times, 8 May, 1875, 7

53 Age, 25 October 1853, 2.

54 "Mr. Amess in Reply, (President of the Contractors' Association), To the Editor of the Age," Age, 29 September, $1874,4$.

55 "The Companies Statute," Victoria Government Gazette, no. 119, 8 September, 1865, 2054

56 Age, 24 January, 1865, 1

57 "Dissolution of Partnership," Victoria Government Gazette, No.69, 18 October, 1872, 1935.

58 Argus, 4 December, 1863, 4.

59 Age, 24 October, 1874, 6.

60 "Death of Mr. D. Mitchell," Argus, 27 March, 1916, 6.

61 "News of the Day," Age, 19 September, 1865, 5.

62 'Tenders - The Melbourne Builders' Lime and Cement
Company - Meeting," Age, 7 October, 1874, 1.

63 "Wanted to Charter a Vessel," Argus, 8 October, 1874, 4.

64 "News of the Day," Age, 20 January, 1875, 2.

65 Taylor, 2017, 60.

66 Geelong Advertiser, 21 January, 1875, 3.

67 Michael Cannon, editor in chief, Historical Records of Victoria: The Crown, the Land and the Squatter 1835-1840 vol.6 (Melbourne: Melbourne University Press 1991), 335.

68 Age, 22 April, 1875, 2.

69 Harrington 2000, 36, citing McClellan 1985, 22.

70 Geelong Advertiser, 6 November, 1874, 3

71 Geelong Advertiser, 10 April, 1875, 2

72 "The Lime Dispute, To the Editor," Geelong Advertiser, 16 October, 1875, 4.

73 “The Lime Quarries Dispute," Geelong Advertiser, 6 February, 1876, 3.

74 "Improvements in Collins Street, Mr. C.H. James's New Building," Age, 28 February, 1888, 6.

75 Cannon 1966, 4.

76 Taylor 2017, 95.

77 "Melbourne, building boom in Melbourne and the difficulty in obtaining bricks," The Ballarat Star, 17 April, 1888, 4.

78 Graeme Davidson, The Rise and Fall of Marvellous Melbourne (Melbourne: Melbourne University Press, 1981), 51.

79 Heritage Council Victoria, Victorian Heritage Database, https://vhd.heritagecouncil.vic.gov.au/places/172, website accessed 19 March 2019.

80 "The Balance of Trade," Age, 25 March, 1890, 5.

81 “The Year's Gold Yield," Age, 7 January, 1890, 5.

82 "The New Melbourne Stock Exchange Building," Age, 18 September, 1889, 6.

83 “The Balance of Trade," Age, 25 March, 1890: 4.

84 Michael Cannon, The Land Boomers, (Melbourne: Melbourne University Press), 1966, 12.

85 "One Standard or Two," Herald, 9 December, 1892, 1.

86 "The Unemployed in Melbourne," Argus, 15 February, 1892,6 . 